\title{
Status Gizi dan Keterpaparan Media Meningkatkan Kejadian Menarche Dini pada Siswi
}

\author{
Nutrition Status and Media Exposure Increase Early Menarche Incidence in Students
}

\author{
Sadiman Sadiman $^{1, \bigotimes}$, Islamiyati Islamiyati ${ }^{1}$ \\ ${ }^{1}$ Jurusan Kebidanan, Poltekkes Kemenkes Tanjungkarang, Indonesia \\ ${ }^{凶}$ Corresponding author: sadiman@poltekkes-tjk.ac.id
}

Kata kunci:
Menarche dini pada siswi,
status gizi siswa,
keterpaparan media.

Keyword:

Menarche early in school girls,

nutritional status of

students,

media exposure.

\begin{abstract}
Abstrak
Latar Belakang: Semakin banyak anak-anak yang mengalami menarche dini, maka semakin besar resiko anak mengalami penyakit keganasan, diantaranya penyakit kanker, terutama kanker payudara. Gizi yang berlebih dan keterpaparan media merupakan faktor pencetus menarche dini. Tujuan:Penelitian ini untuk mengetahui analisis faktor yang berhubungan dengan kejadian Mmenarche dini. Metode: Penelitian ini menggunakan rancangan cross sectional dengan populasi siswi SMP Negeri 4 Metro. Besar sampel penelitian berjumlah 167 siswa yang diambil dengan teknik symple random sampling. Variabel yang diukur dengan observasi dan kuesioner meliputi kejadian menarche dini (variabel dependen) dan status gizi, riwayat usia menarche ibu dan keterpaparan media/elektronik (variabel independen). Analisis data menggunakan uji chi-square. Hasil: Hasil penelitian menunjukkan faktor yang berhubungan dengan menarche dini adalah status gizi lebih/gemuk $(\mathrm{p}=0,009 ; \mathrm{POR}=2,45)$ dan keterpaparan media yang berisiko $(\mathrm{p}=0,046$; POR=2,49). Simpulan: Faktor status gizi dan keterpaparan media/elektronik meningkatkan kejadian menarche dini. Perlu upaya mencegah menarche dini diantaranya dengan menjaga status gizi baik dan mengurangi keterpapan media elektronik.
\end{abstract}

\begin{abstract}
Abstrak
Background: The more children who experience early menarche, the greater the risk of children experiencing malignancy, including cancer, especially breast cancer. Excessive nutrition and media exposure are factors that trigger early menarche. Objective: This study is to determine the analysis of factors associated with the incidence of early Mmenarche. Method: This study used a cross sectional design with a population of students of SMP Negeri 4 Metro. The sample size of the study was 167 students taken by the symple random sampling technique. Variables measured by observations and questionnaires included the occurrence of early menarche (dependent variable) and nutritional status, the age history of maternal menarche and mass or electronic media exposure (independent variable). Data analysis using chi-square test. Results: The results showed that factors related to early menarche were nutritional status ( $p=0.009$; $P O R=2.45)$ and electronic media exposure $(p=0.046 ;$ POR $=2.49)$. Conclusions: Factors of nutritional status and exposure to electrolyte media increase the incidence of early menarche. Efforts are needed to prevent early menarche among others by maintaining good nutritional status and reducing the brightness of electronic media.
\end{abstract}

Copyright $(2019$ Jurnal Kesehatan Metro Sai Wawai. All rights reserved. 


\section{Pendahuluan}

Jumlah remaja di Indonesia mencapai 36 juta jiwa dan 55\% nya adalah remaja putri. Remaja putri di Indonesia mempunyai waktu menarche bervariasi, yaitu antara 10-16 tahun dan rata-rata menarche 12,5 tahun (Wiknjosastro, 2005). Di Indonesia, umur termuda menarche pada remaja putri adalah 9 tahun dan umur tertua menarche pada remaja putri adalah 18 tahun. Kebanyakan remaja putri di Indonesia mengalami menarche pada umur 12 tahun (31,33\%), umur 13 tahun (31,30\%) dan pada umur 14 tahun $(18,24 \%)$. Umur rata-rata menarche terendah terdapat di Jogyakarta 12,45 tahun dan tertinggi di Kupang 13,86 tahun (Batubara, Soesanti, Van der, 2010). Hal ini akibat membaiknya standar kehidupan berdampak pada lebih cepatnya usia menarche (Viayantimala, 2001).

Menarche dini pada perempuan menimbulkan berbagai masalah. Semakin banyak anak-anak yang mengalami menarche dini, maka semakin besar resiko anak mengalami penyakit keganasan, diantaranya penyakit kanker, terutama kanker payudara setelah ia dewasa (Proverawati \& Misaroh, 2009). Marshall dan Faerstein mengemukakan insidensi mioma uteri meningkat signifikan pada wanita yang mengalami menarche sebelum umur 11 tahun. Paparan estrogen yang semakin lama akan meningkatkan insidensi mioma uteri. Menarche dini ( $<10$ tahun) ditemukan meningkatkan resiko relatif mioma uteri, dan menarche lambat (>16 tahun) menurunkan resiko relatif mioma uteri (Parker, 2007). Di Indonesia, data Global Burden Of Center pada tahun 2002 menunjukkan bahwa kanker payudara merupakan kanker terbanyak pada perempuan (26 per 100.000) (Imam, 2010). Jumlah ini juga didukung dengan data yang dikumpulkan oleh SIRS (Sistem Informasi Rumah Sakit) tahun 2007, kanker payudara menempati urutan pertama pada pasien rawat inap di seluruh RS di Indonesia yaitu sebanyak 16,85\% (Yayasan Kanker Indonesia, 2012).

Penelitian yang dilakukan oleh (Munda, Wagey, \& Watamia, 2008) di SMP Kota Manado tentang faktor-faktor yang mempengaruhi usia menarche didapatkan hasil status gizi, genetik, perkembangan informatika, status sosial ekonomi, dan pendidikan. Status gizi menjadi salah satu faktor penting yang berhubungan dengan menarche dini.

SMP Negeri 4 Metro merupakan salah satu SMP favorit. Umumnya dengan ekonomi keluarga menengah ke atas. Status ekonomi menengah keatas cenderung dengan gizi berlebih. Diera informasi membuat siswa banyak terpapar media elektronik untuk anak umur 17 tahun keatas. Gizi yang berlebih dan keterpaparan media merupakan faktor pencetus menarche dini. Studi pendahuluan yang dilakukan terhadap 28 yaitu siswi kelas VII dan kelas VIII siswi diperoleh hasil sebanyak 43\% mengalami menstruasi dini. Penelitian ini bertujuan menganalisis faktor-faktor risiko terjadinya menarche dini pada para siswi.

\section{Metode}

Penelitian ini merupakan penelitian analitik dengan rancangan penelitian cross sectional, yaitu suatu penelitian untuk mempelajari dinamika korelasi antara faktor-faktor risiko dengan efek dengan cara pendekatan observasi atau pengumpulan data sekaligus pada suatu saat. Penelitian ini untuk mengetahui hubungan faktor status gizi, keterpaparan media massa, riwayat menarche ibu, dengan kejadian menarche dini pada siswi SMP Negeri 4 Metro. Populasi dalam penelitian ini adalah siswi kelas siswi SMP Negeri 4 Metro jumlah 302 siswa. Sampel dalam penelitian ini adalah yaitu siswi SMP Negeri 4 Metro yang sudah mengalami menstruasi yang dihitung dengan rumus Slovin diperoleh jumlah sampel penelitian 167 orang. Teknik sampling yang digunakan adalah teknik random sampling yaitu pengambilan sanmpel secara simple random sampling dengan cara diundi.

Pengumpulan data dilakukan dengan menggunakan kuesioner dan observasi. Variabel yang diukur meliputi kejadian menarche dini (variabel dependen) dan status gizi, riwayat usia menarche ibu dan keterpaparan media massa atau elektronik (variabel independen). Alat ukur yang digunakan adalah timbangan dewasa dan microtoise dan kuesioner dengan hasil ukur masing-masing: (1) pemeriksaan 
status gizi dengan cara mengukur berat badan $(\mathrm{kg})$ dibandingkan tinggi badan (meter) dan (2) pengukuran tinggi badan menggunakan alat ukur microtoise dan berat badan dengan timbangan dewasa. Kuesioner digunakan untuk mengumpulkan keterpaparan siswi dengan media elektronik/media massa, dan status menarche ibu dan untuk riwayat menarche ibu responden bertanya ibunya secara langsung.

Data hasil penelitian dilakukan analisis univariat menggunakan distribusi frekuensi dan analisis bivariat. Analisis bivariat dilakukan untuk melihat hubungan status gizi, keterpaparasn siswi dengan media elektronik/media massa, dan status menarche ibu dengan kejadian menarche dini menggunakan uji chi square dengan derajat kemaknaan menggunakan kepercayaan (confident interval) $95 \%$ dan tingkat kesalahan $(\alpha)=5 \%$.

\section{Hasil}

\section{Kejadian menarche dini}

Hasil penelitian pada tabel 1 dapat diketahui dari 167 orang responden 167 siswi SMP Negeri 4 Metro yang mengalami menarche dini berjumlah 40,7\%, status gizi berisiko dengan katagori gemuk $29,9 \%$. Sedangkan, ibu dengan riwayat yang mengalami menarche dini berjumlah $13,8 \%$ orang dan responden yang terpapar media massa/elektronik dengan durasi tinggi terdapat $82,6 \%$ orang.

Tabel 1.

Distribusi frekuensi kejadian menarche dini, status gizi, usia menarche ibu, dan keterpaparan media massa Siswi SMP Negeri 4 Metro

\begin{tabular}{|c|c|c|c|}
\hline Variabel & Kategori & $\begin{array}{c}\text { Frekuensi } \\
n=167\end{array}$ & $\begin{array}{c}\% \\
\mathrm{n}=100\end{array}$ \\
\hline \multirow[t]{2}{*}{ Kejadian Menarche Dini } & $\mathrm{Ya}$ & 68 & 40.7 \\
\hline & Tidak & 99 & 59.3 \\
\hline \multirow[t]{2}{*}{ Status Gizi } & Normal dan kurang (tidak berisiko) & 117 & 70.1 \\
\hline & Gemuk dan obesitas (berisiko) & 50 & 29.9 \\
\hline \multirow[t]{2}{*}{ Usia Menarche Ibu } & Menarche dini $(\leq 11$ tahun $)$ & 23 & 13.8 \\
\hline & Menarche sesuai usia (>11 tahun) & 144 & 86.2 \\
\hline \multirow[t]{2}{*}{ Keterpaparan media massa/ elektronik } & Terpapar Rendah & 29 & 17.4 \\
\hline & Terpapar Tinggi & 138 & 82.6 \\
\hline
\end{tabular}

\section{Analisis Bivariat}

Hubungan status gizi dengan kejadian menarche dini

Tabel 2 menunjukkan analisis bivariat dengan uji chi square dengan hasil: (1) ada hubungan antara status gizi terhadap kejadian menarche dini pada siswi SMP Negeri 4 Metro ( $\mathrm{p}=0,009$; $\mathrm{POR}=2,45$ ) dan responden yang mengalami kegemukakan berisiko mengalami menstruasi dini sebesar 2,45 kali lebih besar dibandingkan siswi yang normal atau kurus; (2) tidak ada hubungan antara riwayat usia menarche ibu dengan kejadian menarche dini $(\mathrm{p}=0,097 ; \mathrm{p}>\alpha(0,05)$; tidak ada hubungan antara riwayat usia menarchei dan responden dengan ibu riwayat menarche dini akan berisiko mengalami menstruasi dini sebesar 2,104 kali lebih besar dibandingkan siswi dengan ibu tanpa riwayat menarche dini; (3) ada hubungan yang bermakna antara keterpaparan media dengan menarche dini ( $\mathrm{p}=0,046$; $\mathrm{POR}=2,49$ ) dan responden yang keterpaparan media tinggi berisiko mengalami menstruasi dini 2,49 kali lebih besar dibandingkan siswi yang keterpaparan media rendah (lihat tabel 2).

\section{Pembahasan}

\section{Kejadian menarche dini}

Menarche merupakan periode menstruasi yang pertama terjadi pada masa pubertas seorang anak perempuan, biasanya terjadi pada usia 10-16 tahun (Proverawati \& Misaroh, 2009). Hasil penelitian 
Tabel 2.

Hubungan status gizi, riwayat menarche ibu, dan keterpaparan media dengan menarche dini

\begin{tabular}{|c|c|c|c|c|c|c|c|c|}
\hline \multirow{3}{*}{ Variabel } & \multicolumn{4}{|c|}{ Menarche Dini } & \multirow{2}{*}{\multicolumn{2}{|c|}{ Total }} & \multirow{3}{*}{ p-value } & \multirow{3}{*}{ POR } \\
\hline & \multicolumn{2}{|c|}{$\mathrm{Ya}$} & \multicolumn{2}{|c|}{ Tidak } & & & & \\
\hline & $\mathrm{n}$ & $\%$ & $\mathrm{n}$ & $\%$ & $\mathrm{n}$ & $\%$ & & \\
\hline \multicolumn{9}{|l|}{ Status Gizi } \\
\hline Gemuk dan over weight (berisiko) & 22 & 44 & 28 & 56 & 50 & 100 & \multirow[t]{2}{*}{0,009} & \multirow[t]{2}{*}{2,450} \\
\hline Normal dan kurus (tidak berisiko ) & 77 & 66 & 40 & 34 & 177 & 100 & & \\
\hline \multicolumn{9}{|l|}{ Riwayat Menarche Ibu } \\
\hline Menarche dini ( $\leq 11$ tahun ) & 89 & 62 & 55 & 38 & 144 & 100 & \multirow[t]{2}{*}{0.097} & \multirow[t]{2}{*}{2,104} \\
\hline Menarche sesuai usia (>11 tahun) & 10 & 43,5 & 13 & 56,5 & 23 & 100 & & \\
\hline \multicolumn{9}{|l|}{ Keterpaparan Media } \\
\hline Terpapar tinggi & 77 & 56 & 61 & 44 & 138 & 100 & \multirow[t]{3}{*}{0,046} & \multirow[t]{3}{*}{2,490} \\
\hline Terpapar rendah & 22 & 76 & 7 & 24 & 29 & 100 & & \\
\hline Jumlah & 99 & 59 & 68 & 41 & 167 & 100 & & \\
\hline
\end{tabular}

yang dilakukan terhadap 167 responden di SMP Negeri 4 Metro menunjukkan bahwa terdapat 40,7\%)yang mengalami menarche dini. Hampir setengah siswa mengalami menarche dini. Hasil penelitian ini sesuai dengan penelitian yang dilakukan oleh (Pujiani, 2010) dilaporkan sebanyak 21 responden $(58,3 \%)$ sudah mengalami menstruasi pertama pada usia 10 tahun. Hasil penelitian ini lebih tinggi dari penelitian yang dilakukan oleh (Susanti, 2012) mengungkapkan bahwa, 35 responden $(23,6 \%)$ dari 70 responden di SMP Negeri 30 Semarang, dilaporkan telah mengalami menarche dini pada rentang usia 10 tahun. Penelitian (Wulandari, Aini, \& Astuti, 2012) didapatkan hasil proporsi menarche dini sebsar $31,8 \%$.

Menurut (Proverawati \& Misaroh, 2009) yang menjelaskan bahwa usia menarche anak perempuan di Amerika mengalami penurunan mencapai $40 \%$ dari usia yang seharusnya, yakni 12 tahun. Di Indonesia menunjukkan angka yang sama yaitu usia menarche kurang dari 9 tahun. Di Jawa Tengah khususnya kota Semarang, sekitar $0,1 \%$ anak-anak mengalami menarche lebih awal pada usia 8 tahun (Kusuma, 2010). Menarche dini diupayakan minimal terjadi pada anak-anak, dengan menghindari berbagai faktor terjadinya. Akibat menarche dini pada perempuan setelah dewasa dapat menimbulkan masalah baru, diantaranya kanker payu dara. Menarche dini ( $<10$ tahun) ditemukan meningkatkan resiko relatif mioma uteri, dan menarche lambat ( $>16$ tahun) menurunkan resiko relatif mioma uteri (Parker, 2007).

\section{Status gizi dan kejadian menarche dini}

Status gizi merupakan faktor risiko terjadinya mengalami menarche dini. Hasil penelitian ini menunjukkan responden dengan gizi lebih/gemuk berjumlah $29,9 \%$ dan yang mengalami mengalami menarche dini terdapat $44 \%$. Hasil analisis ada hubungan yang bermakna antara status gizi dengan kejadian menarche dini pada siswi SMP Negeri 4 Metro. Responden yang mengalami kegemukakan berisiko mengalami menstruasi dini sebesar 2,45 kali lebih besar dibandingkan siswi yang normal atau kurus $(\mathrm{POR}=2,45)$. Penelitian ini sejalan dengan penelitian yang dilakukan oleh (Munda, Wagey, \& Watamia, 2008) di Manado dan penelitian oleh (Putra, Ernawati, \& Amir, 2016) di SMP N 1 Padang dengan hasil terdapat hubungan bermakna secara statistik IMT dengan menarche dini.

Nutrisi akan mempengaruhi seksual pada remaja putri yang mendapat menarche lebih dini, mereka cenderung dengan tubuh lebih berat dan lebih tinggi pada saat menarche dibandingkan dengan mereka yang belum menstruasi pada usia yang sama. Sebaliknya pada remaja putri yang mengalami menarche yang terlambat, kondisi berat badan lebih ringan dari pada yang sudah menstruasi dengan usia yang sama dan tinggi badan mereka sama. Umumnya mereka menjadi matang lebih dini akan memiliki 
indeks massa tubuh (IMT) yang lebih tinggi, dan mereka yang matang terlambat menstruasi, memiliki IMT lebih kecil pada usia yang sama (Soetjiningsih, 2004).

Status gizi lebih dan gemuk juga kandungan lemak berlebih. Lebih lanjut (Dieny, 2014) menjelaskan lemak di dalam tubuh berhubungan dengan produksi hormon, jika lemak di dalam tubuh berlebih produksi hormon tubuh juga akan berlebih. Hasil penelitian oleh Aryati menemukan bahwa faktor faktor usia menarche sebagai faktor yang paling berpengaruh dengan usia menarche. Semakin tinggi kandungan lemak tubuh, maka semakin dini usia menarche anak (Aryani, 2016). Oleh karena itu, status gizi berlebih dan gemuk pada anak perlu dicegah sejak dini, untuk mencegah terjadi menarche dini.

\section{Keterpaparan media dengan kejadian menarche dini}

Keterpaparan anak dengan media untuk usia dewasa > 17 tahun menjadi bagian yang mempercepat terjadinya manarche dini. Hasil penelitian menunjukkan keterpaparan media massa berhubungan bermakna dengan kejadian menarche dini di SMP Negeri 4 Metro. Responden yang keterpaparan media tinggi berisiko mengalami menstruasi dini 2,49 kali lebih besar dibandingkan siswi yang keterpaparan media rendah terhadap berbagai media atau vidio untuk orang dewasa ( $>17$ tahun).

Penelitian ini sesuai dengan penelitian (Kusuma, 2010) tentang hubungan faktor siswa dengan kejadian menarche pada remaja putri di SMP 11 Semarang. Hasil menunjukkan paparan audio visual mempengaruhi menarche dini. Anak-anak yang sering mengakses situs internet dan menyaksikan tayangan dewasa yang seharusnya belum dikonsumsi anak usia tersebut dapat merangsang hipotalamus anak untuk mengikuti apa yang diinformasikan di situs tersebut, baik yang berdampak positif ataupun negatif. Rangsangan tersebut masuk ke panca indra menuju pusat rangsang, kemudian hipotalamus merangsang pematangan hormon estrogen dan progesteron lalu memberikan umpan balik ke pusat panca indra, sehingga hormon berfluktuasi. Hal ini mempengaruhi kematangan hormon reproduksi anak sehingga anak mengalami menarche dini (Pakhri, 2010).

Hendaknya orang tua dan guru sekolah meningkatkan bimbingan agar anak terhindar dari terpapar media atau vidio untuk orang dewasa (> 17 tahun), hal ini dapat menghindari terjadi menarche dini dan dampaknya pada usia dewasa. Karena menarche dini pada perempuan dapat menimbulkan berbagai masalah. Semakin banyak anak-anak yang mengalami menarche dini, maka semakin besar resiko anak mengalami penyakit keganasan, diantaranya penyakit kanker, terutama kanker payudara setelah ia dewasa (Proverawati \& Misaroh, 2009).

\section{Simpulan dan Saran}

Penelitian menyimpulkan bahwa responden yang mengalami menarche dini berjumlah 40,7\% . Faktor status gizi kegemukan meningkatkan risiko 2,45 kali mengalami menarche dini, sedangkan faktor keterpaparan media massa/elektronik meningkatkan risiko mengalami 2,49 dengan menarche dini. Pihak SMP Negeri 4 Metro agar dapat berupaya melakukan treatment pada anak yang mengalami menarche dini yang meliputi: pengukuran status gizi sehingga dapat mengontrol IMT dengan mengurangi kalori pada anak yang mengalami kelebihan berat badan. Membatasi anak dengan terpaparnya media elektronik yang isinya dipeuntukkan pada oarang dewasa atau 17 tahun keatas seperti nonton film atau megakses berita yang negatif/porno sehingga dapat merangsang hormon yang memicu menarche dini.

\section{Referensi}

Aryati. (2007). Usia menarche pada siswi SD dan SLTP di kota Bandung. Jurnal Kesehatan Masyarakat Nasional. $2(6)$.

Batubara, J.R., Soesanti, F., Van der, W.H.D. (2010). Age at menarche in Indonesian girls: a national survey. Acta Med Indones. 42(2): 78-81. 
Dieny, F. F. (2014). Permasalahan gizi pada remaja putri . Yogyakarta: Graha Ilmu.

Imam, R. (2010). Epidemiologi kanker pada wanita. Jakarta: Sagung Seto.

Kusuma, D. A. (2013). Hubungan beberapa faktor siswi dengan kejadian menarche dini pada remaja awal di SMPN 11 Kota Semarang. Institusional Repository Undip. Retrieved November 13, 2017, from http://ejournals1.Undip.ac.id/index.php/jkm

Munda, S. S., Wagey, F. W., \& Watamia, J. (2008). Hubungan IMT dengan usia menarche pada siswi SD dan SMP di Kota Manado. Retrieved November 15, 2017, from Bagian Obstetri dan Ginekologi Fakultas Kedokteran Universitas Sam Ratulangi: http://ejournal.unsrat.ac.id/index.php/eclinic/article/

Pakhiri, A. (2012). Hubungan antara siaran televisi dan status gizi terhadap status menarche pada Siswi SMP Negeri 5 Tinambun Kabupaten Polman. Jurnal Media Gizi Pangan. Retrieved November 15, 2017, from jurnalmediagizipangan.files.wordpress.com.

Parker, W.H. (2007). Etiologi, symptomaatology \& diagnosis of uterine myomas. Departemen of Obstetric \& Gynecology UCLA School Medicine. California: American Society For Reproduktive Medicine.

Proverawati, A., \& Misaroh, S. (2009). Menarche menstruasi pertama penuh makna. Yogyakarta: Nuha Medika.

Pujiani. (2010). Hubungan Status Gizi dengan Usia Menarche. Skripsi. Fakultas Ilmu Kesehatan Universitas Pesantren Tinggi Darul Ulum .

Putra, Y. N., Ernawati, \& Amir, A. (2016). Hubungan Indek Massa Tubuh dengan usia menarche pada Siswa SMP Negeri 1 Padang. Jurnal Kesehatan Andalas. 5(3), 551-557. DOI: https://doi.org/10.25077/jka.v5.i3.p\%25p.2016

Soetjiningsih. (2004). Tumbuh kembang remaja dan permasalahannya. Jakarta: Sagung Seto.

Susanti, A. V. (2012). Faktor resiko kejadian menarche dini pada remaja SMPN 30 Semarang. Journal of Nutrition College. 1(1), 125-126. DOI: https://doi.org/10.14710/jnc.v1i1.673

Viayantimala, L. (2001). Hubungan status gizi dengan menarche (Studi Kasus pada Siswa SLTP Perkotaan dan Pedesaan di Pekalongan.

Wiknjosastro. (2005). Ilmu kebidanan. Jakarta: Yayasan Bina Pustaka-Sarwono Prawirohardjo.

Wulandari, P., Aini, N. D., \& Astuti, W. S. (2012). Faktor-faktor yang berhubungan dengan menarche Siswi SMP 31 Semarang. Stikes Widya Husada .

Yayasan Kanker Indonesia. (2012). Retrieved November 31, 2017, from YKI- Jakarta Race: http://yayasankankerindonesia.org/2012/yki.jakarta-race/ 